\title{
Neuroimaging findings of babies with microcephaly and presumed congenital Zika virus infection
}

\author{
Images add to evidence that Zika virus causes microcephaly
}

\section{Tiago Baptista consultant neuroradiologist ${ }^{1}$, Gerardine Quaghebeur consultant neuroradiologist ${ }^{1}$, Ana Alarcon consultant neonatologist ${ }^{2}$}

${ }^{1}$ Department of Neuroradiology, Oxford University Hospitals NHS Foundation Trust, Oxford OX3 9DU, UK; ${ }^{2}$ Neonatal Unit, Oxford University Hospitals NHS Foundation Trust

Microcephaly results from reduced brain growth. Affected infants are born with a smaller head size than normal, or their head stops growing after birth. It is a rare condition with estimated incidences varying geographically; in the United States reported incidence ranges from 2 to 12 babies per 10000 live births. The causes are numerous, including chromosomal abnormalities, intrauterine infections, exposure to toxic substances during pregnancy, and severe malnutrition.

Coinciding with an outbreak of Zika virus in the Americas, the estimated prevalence of microcephaly in some areas has increased by a factor of 20. ${ }^{1}$ There has been much discussion about the potential link between Zika virus infection, microcephaly, and other brain malformations. After a rigorous review of existing evidence, scientists from the Centers for Disease Control and Prevention last week concluded that the link is causal. ${ }^{2}$

The BMJ paper by Vasco Aragao and colleagues (doi:10.1136/ bmj.i1901) ${ }^{3}$ is the second detailed evaluation of a cohort of Brazilian infants with microcephaly. ${ }^{4}$ In both case series, clinical and epidemiological findings were compatible with congenital Zika virus infection, and anti-Zika virus IgM antibodies were detected in the cerebrospinal fluid of some infants, further supporting a causal relation between Zika virus infection and brain abnormalities.

The paper by Vasco Aragao and colleagues is the first to report findings from magnetic resonance imaging (MRI) as well as computed tomography (CT). The CT images show previously described cerebral calcifications predominantly at the junction between the cortex and subcortical white matter, with associated loss of brain volume and other non-specific features. The novelty of the MRI scans is that they show the severe cortical malformations and other features more clearly. In particular, they show a prominence of cortical malformations in the frontal lobes, mainly polymicrogyria and pachygyria (disruptions of neuronal migration).
Many of these findings are seen in infants with other congenital infections such as cytomegalovirus, rubella, and toxoplasmosis. The location of calcifications and the frontal nature and symmetry of the abnormalities are less typical of those infections, although they sometimes occur in infants with other conditions such as Aicardi-Goutières syndrome (a rare autosomal recessive neurodegenerative disorder).

The importance of these findings is that they should alert clinicians, particularly radiologists and paediatricians, to the likelihood of congenital Zika virus infection in infants referred with microcephaly, when maternal history is compatible geographically with exposure to Zika virus in the first or second trimester of pregnancy. Since MRI was able to identify more abnormalities with greater clarity than CT, MRI should be the investigation of choice where available. This option also avoids exposing infants to the ionising radiation delivered by CT.

The Emergency Committee of the World Health Organizaion has declared the Zika virus outbreak a public health emergency of international concern. ${ }^{5}$ This arbovirus is transmitted by the mosquitoes Aedes aegypti (the main vector worldwide) and Aedes albopictus. ${ }^{6}$ The risk of transmission of the Zika virus in Europe should not be underestimated. A albopictus is present in 20 European countries and will become active in late spring and summer. By that time, the risk of transmission from travellers infected in the Americas may increase. ${ }^{7}$ Sexual transmission and transmission by blood transfusion have also been described, with associated implications for all travellers to endemic areas, and for the female partners of men travelling to these areas. ${ }^{8}$ Urgent research priorities include improved diagnostic tests (especially important during pregnancy), vector control, and the development of both vaccines and specific treatments.

The findings by Vasco Aragao and colleagues will help improve the diagnosis of congenital Zika virus infection and contribute to the public health response globally. The reported cases probably represent only the more severely affected infants. 
Identification of those with milder forms of congenital infection and research on the long term neurodevelopmental outcomes of all affected infants will be vital.

Questions remain about whether the surge in reported cases of microcephaly is entirely due to Zika virus infection, and whether heightened awareness and improved reporting may have led to some overestimation of the link. The risk of microcephaly after maternal infection is estimated at roughly one in 100 women. ${ }^{9}$ This is a relatively low risk compared with other causal infections such as cytomegalovirus. The risk to the fetus from Zika virus infection may prove to be lower in the end than the risk from other infective causes of microcephaly. The risk may even disappear eventually, once local populations gain herd immunity. ${ }^{9}$ Risks will of course remain for all non-immune travellers to endemic areas, and research in to microcephaly caused by maternal Zika virus infection remains a global priority.

Competing interests: We have read and understood BMJ policy on declaration of interests and declare the following: none.

Provenance and peer review: Commissioned; not externally peer reviewed.
1 Kleber de Oliveira W, Cortez-Escalante J, De Oliveira WTGH, et al. Increase in Reported Prevalence of Microcephaly in Infants Born to Women Living in Areas with Confirmed Zika Virus Transmission During the First Trimester of Pregnancy - Brazil, 2015. MMWR Morb Mortal Wkly Rep 2016;65:242-7.www.cdc.gov/mmwr/volumes/65/wr/mm6509e2. htmdoi:10.15585/mmwr.mm6509e2 pmid:26963593.

2 Rasmussen SA, Jamieson DJ, Honein MA, Petersen LR. Zika Virus and Birth Defects Reviewing the Evidence for Causality. N Engl J Med 2016 Apr 13;NEJMsr1604338. www. nejm.org/doi/10.1056/NEJMsr1604338

3 de Fatima Vasco Aragao M, van der Linden V, Brainer-Lima AM, et al. Clinical features and neuroimaging (CT and MRI) findings in presumed Zika virus related congenital infection and microcephaly: retrospective case series study. BMJ 2016;353:11901.www.bmj.com/ lookup/doi/10.1136/bmj.i1901doi:10.1136/bmj.i1901 pmid:27075009.

4 Hazin AN, Poretti A, Cruz DDCS, et al. Computed Tomographic Findings in Microcephaly Associated with Zika Virus. N Engl J Med 2016 Apr 6;NEJMc1603617. www.nejm.org/ doi/10.1056/NEJMc1603617

$5 \mathrm{WHO}$ / WHO Director-General summarizes the outcome of the Emergency Committee regarding clusters of microcephaly and Guillain-Barré syndrome. World Health Organization; [cited 2016 Apr 10]; www.who.int/mediacentre/news/statements/2016/ emergency-committee-zika-microcephaly/en/\#.Vwp3qEzFm7M.mendeley

6 Surveillance and Control of Aedes aegypti and Aedes albopictus in the United States [Internet]. www.cdc.gov/chikungunya/resources/vector-control.html

7 World Health Organization - Regional Office for Europe. Zika virus vectors and risk of spread in the WHO European Region www.euro.who.int/_data/assets/pdf_file/0007/ 304459/WEB-news_competence-of-Aedes-aegypti-and-albopictus-vector-species.pdf

8 Lucey DR. Time for global action on Zika virus epidemic. BMJ 2016;352:i781.www.bmj. com/lookup/doi/10.1136/bmj.i781doi:10.1136/bmj.i781 pmid:26856896.

9 Doshi P. Convicting Zika. BMJ 2016;353:11847.www.bmj.com/lookup/doi/10.1136/bmj. i1847doi:10.1136/bmj.i1847 pmid:27056643.

Published by the BMJ Publishing Group Limited. For permission to use (where not already granted under a licence) please go to http://group.bmj.com/group/rights-licensing/ permissions 